\title{
Lower cortisol levels and attenuated cortisol reactivity to daily-life stressors in adults with $22 q 11.2$ deletion syndrome
}

Citation for published version (APA):

van Duin, E. D. A., Vaessen, T., Kasanova, Z., Viechtbauer, W., Reininghaus, U., Saalbrink, P., Vingerhoets, C., Hernaus, D., Booij, J., Swillen, A., Vorstman, J., van Amelsvoort, T., \& Myin-Germeys, I. (2019). Lower cortisol levels and attenuated cortisol reactivity to daily-life stressors in adults with $22 q 11.2$ deletion syndrome. Psychoneuroendocrinology, 106, 85-94.

https://doi.org/10.1016/j.psyneuen.2019.03.023

Document status and date:

Published: 01/08/2019

DOI:

10.1016/j.psyneuen.2019.03.023

Document Version:

Publisher's PDF, also known as Version of record

\section{Document license:}

Taverne

Please check the document version of this publication:

- A submitted manuscript is the version of the article upon submission and before peer-review. There can be important differences between the submitted version and the official published version of record.

People interested in the research are advised to contact the author for the final version of the publication, or visit the DOI to the publisher's website.

- The final author version and the galley proof are versions of the publication after peer review.

- The final published version features the final layout of the paper including the volume, issue and page numbers.

Link to publication

\footnotetext{
General rights rights.

- You may freely distribute the URL identifying the publication in the public portal. please follow below link for the End User Agreement:

www.umlib.nl/taverne-license

Take down policy

If you believe that this document breaches copyright please contact us at:

repository@maastrichtuniversity.nl

providing details and we will investigate your claim.
}

Copyright and moral rights for the publications made accessible in the public portal are retained by the authors and/or other copyright owners and it is a condition of accessing publications that users recognise and abide by the legal requirements associated with these

- Users may download and print one copy of any publication from the public portal for the purpose of private study or research.

- You may not further distribute the material or use it for any profit-making activity or commercial gain

If the publication is distributed under the terms of Article $25 \mathrm{fa}$ of the Dutch Copyright Act, indicated by the "Taverne" license above, 


\title{
Lower cortisol levels and attenuated cortisol reactivity to daily-life stressors in adults with 22q11.2 deletion syndrome
}

\author{
Esther D.A. van Duin ${ }^{\mathrm{a}, \mathrm{d}}$, Thomas Vaessen ${ }^{\mathrm{b}, *}$, Zuzana Kasanova ${ }^{\mathrm{b}}$, Wolfgang Viechtbauer ${ }^{\mathrm{a}}$, \\ Ulrich Reininghaus $^{\mathrm{a}, \mathrm{c}}$, Peter Saalbrink ${ }^{\mathrm{a}}$, Claudia Vingerhoets ${ }^{\mathrm{a}, \mathrm{d}}$, Dennis Hernaus ${ }^{\mathrm{a}}$, Jan Booij ${ }^{\mathrm{d}}$, \\ Ann Swillen ${ }^{\mathrm{e}, \mathrm{f}}$, Jacob Vorstman ${ }^{\mathrm{g}, \mathrm{h}}$, Thérèse van Amelsvoort ${ }^{\mathrm{a}, 1}$, Inez Myin-Germeys ${ }^{\mathrm{b}, 1}$ \\ ${ }^{a}$ Department of Psychiatry \& Neuropsychology, Maastricht University, Maastricht, the Netherlands \\ ${ }^{\mathrm{b}}$ Center for Contextual Psychiatry, Department of Neurosciences, KU Leuven, Leuven, Belgium \\ ${ }^{\mathrm{c}}$ Centre for Epidemiology and Public Health, Health Service and Population Research Department, Institute of Psychiatry, Psychology \& Neuroscience, King's College \\ London, London, UK \\ ${ }^{\mathrm{d}}$ Department of Radiology and Nuclear Medicine, Amsterdam University Medical Centers, location Academic Medical Center, Amsterdam, the Netherlands \\ e Department of Human Genetics, KU Leuven - Leuven University, Leuven, Belgium \\ ${ }^{\mathrm{f}}$ Center for Human Genetics, Hospital Gasthuisberg, Leuven, Belgium \\ ${ }^{\mathrm{g}}$ Department of Psychiatry, The Hospital for Sick Children and University of Toronto, Toronto, ON, Canada \\ ${ }^{\mathrm{h}}$ Program in Genetics and Genome Biology, Research Institute, The Hospital for Sick Children, Toronto, ON, Canada
}

\section{A R T I C L E I N F O}

\section{Keywords:}

Cortisol

Experience sampling method

22q11.2 deletion syndrome

Stress reactivity

\begin{abstract}
A B S T R A C T
Background: 22q11.2 deletion syndrome (22q11DS) is a genetic disorder associated with neurodevelopmental, anxiety and mood disorders, as well as an increased risk for developing psychosis. Cortisol levels and stress reactivity reflect hypothalamic-pituitary-adrenal (HPA)-axis activity, and are believed to be altered in individuals that often experience daily-life stress, depression, and psychotic symptoms. However, it is unknown whether individuals with 22q11DS display an altered stress reactivity.

Methods: We included 27 adults with 22q11DS (mean age: 34.1 years, $67 \%$ female) and 24 age and sex-matched healthy controls (HC; mean age: 39.9 years, 71\% female) into an experience sampling study. Throughout 6 consecutive days, we measured participants' subjective stress related to current activity and at the same time collected salivary cortisol samples. Multilevel regression models were used to analyze cortisol reactivity to activity-related stress.

Results: Diurnal cortisol levels were significantly lower in the 22q11DS group compared to HCs $(B=-1.03$, $\mathrm{p}<0.001)$. 22q11DS adults displayed significantly attenuated cortisol reactivity to activity-related stress compared to HCs $(B=-0.04, p=0.026)$. Post-hoc exploratory analysis revealed that these results were independent from 22q11DS psychiatric diagnosis or medication use.

Conclusion: These results indicate that adults with 22q11DS have lower cortisol levels and attenuated cortisol response to daily stress, possibly resulting from an increased sensitization of the HPA-axis. This suggests that alterations in HPA-axis functioning, previously reported in several psychiatric disorders including post-traumatic stress disorder (PTSD), psychotic disorder, and mood disorder, also appear to be present in adults with 22q11DS.
\end{abstract}

\section{Introduction}

The 22q11.2 deletion syndrome (22q11DS) is a genetic disorder caused by a microdeletion on the long arm of the 22nd chromosome, resulting in hemizygosity of approximately 50 genes (Murphy et al., 1999; Bassett et al., 2005; Schneider et al., 2014; McDonald-McGinn et al., 2015; Gur et al., 2017). Occurring in 1 out of 2000-4000 live births, it is one of the most common recurrent copy number variant disorders. The syndrome is associated with impairments in socio-emotional functioning (e.g., deficits in socialization, comprehension and social judgment) and somatic health (e.g., cardiac abnormalities, facial dysmorphology, immunodeficiencies, and early-onset Parkinson's disease)(Bassett et al., 2005; Schneider et al., 2014; Fung et al., 2015). In addition, patients generally have intellectual impairments, varying

\footnotetext{
* Corresponding author at: Department of Psychiatry, MHeNS, P.O. Box 616 (VIJV-SN2), 6200 MD Maastricht, the Netherlands.

E-mail address: thomas.vaessen@kuleuven.be (T. Vaessen).

${ }^{1}$ Shared last authorship.
} 
from borderline IQ to moderate-severe intellectual disability (average IQ of 70-85)(Bassett et al., 2005; Schneider et al., 2014), and a high risk of developing mental disorders, including mood disorders (23-53\%), attention deficit hyperactivity disorder (36\%), autism spectrum disorder (25-50\%), and psychosis (20-40\%)(Vorstman et al., 2006; Green et al., 2009; Schneider et al., 2014).

It has been suggested that the wide variety of physical and mental health problems is partially related to the high rates of chronic stress in individuals with 22q11DS (Beaton and Simon, 2011). The clinical phenotype of 22q11DS includes greater susceptibility to stress and anxiety, and poorer coping skills (Swillen et al., 1999; Beaton and Simon, 2011). Moreover, since children with 22q11DS often have to face medical (e.g., frequent hospitalizations and surgery (Mahle et al., 2003; Carotti et al., 2008)), cognitive (e.g., delayed cognitive development)(Gur et al., 2014; Swillen and McDonald-McGinn, 2015), and social challenges (e.g., bullying) (Swillen et al., 1999)) early in life, it is very likely that they may experience chronic stress, especially in infancy (Beaton and Simon, 2011; Vo et al., 2018). However, no study to date has investigated whether individuals with 22q11DS and healthy controls (HCs) differ in their experience of- and exposure to childhood adversity and chronic stress.

Early-life stress can have several persisting effects, which include epigenetic alterations (Jawahar et al., 2015), impaired brain development (Andersen et al., 2008; De Bellis and Zisk, 2014), and an increased risk of developing psychiatric disorders (Green et al., 2010; Kessler et al., 2010; Varese et al., 2012; Jawahar et al., 2015). Meanwhile, stressful events during adulthood are thought to increase risk for psychiatric disorders in vulnerable individuals, and may precede the onset of a psychotic episode (Lukoff et al., 1984; Corcoran et al., 2003).

The ability to adaptively respond to stressful events is modulated by hypothalamic-pituitary-adrenocortical (HPA) axis activity: the stressregulating system secreting cortisol in response to (potentially) stressful events (Nicolson, 2008). It is suggested that long term exposure to stress and excessive activation of the HPA-axis can alter HPA-axis functioning and cause sensitization of the stress response (McEwen, 2004). Cortisol follows a diurnal curve with a stark rise shortly after awakening, followed by a gradual decrease over the day. Flattened curves are associated with poorer physical and mental health (Adam et al., 2017), possibly due to HPA-axis dysfunction. Impaired cortisol reactivity in general is associated with psychiatric disorders (Holtzman et al., 2013; Zorn et al., 2017) also often reported in 22q11DS (Schneider et al., 2014; Fung et al., 2015) including depression (Kendler et al., 1999), anxiety (Moreno-Peral et al., 2014) and psychosis (Holtzman et al., 2013).

Given the abovementioned relevance of stress reactivity for mental and somatic health, it is rather surprising that little attention has been paid to the HPA axis function in 22q11DS adults. To our knowledge, only two studies (both in children) investigated cortisol and stress reactivity in 22q11DS individuals (Jacobson et al., 2016; Sanders et al., 2017). Jacobson and colleagues (Jacobson et al., 2016) found increased end-of-the-morning cortisol levels (collected around 11:00 h) in a sample of 11 children with 22q11DS compared to HC. Another study investigating cortisol reactivity to a stressful working memory task, did not find significant differences in cortisol reactivity and recovery in relation to the task in 20 children with 22q11DS (Sanders et al., 2017). However, compared to HCs, an overall increase in afternoon salivary cortisol levels in 22q11DS relative to HCs were detected, potentially indicating abnormal HPA-axis functioning in this group. Interestingly recent work in 22q11DS also confirms the central role of stress and coping in the pathway to psychosis in 22q11DS (Armando et al., 2018).

Studies using the experience sampling method (ESM) (MyinGermeys et al., 2018), a structured diary technique, showed increased stress sensitivity (here, the emotional responses (positive and negative affect) to daily stress events) in (non-22q11DS) individuals with psychotic disorder and first-degree relatives of these patients (MyinGermeys et al., 2009; Reininghaus et al., 2016). ESM can be used for assessment of situational variables, outside of an artificial clinical or laboratory setting (Bolger et al., 2003; Myin-Germeys and van Os, 2007), and has previously been used to investigate cortisol reactivity to stressful events in clinical and non-clinical populations (Peeters et al., 2003; Jacobs et al., 2007; Collip et al., 2011a,b). ESM is exceptionally suitable for investigating cortisol fluctuations and responses to environmental challenges (i.e., stressors) (Peeters et al., 2003; Jacobs et al., 2007; Collip et al., 2011a,b). In first-degree relatives of patients with psychotic disorders, higher overall cortisol levels and increased cortisol response to daily life stressors have been found (Collip et al., 2011a,b). Another recent ESM study reported an altered cortisol response to stressful activities in patients with psychotic disorders compared to HCs (Vaessen et al., 2018). ESM is therefore a suitable method to investigate stress reactivity in individuals with 22q11DS, and has never been used in this population before.

To summarize, individuals with 22q11DS show increased susceptibility to stress and anxiety, and may be more exposed to and experiencing chronic (childhood) stress compared to HCs. Haploinsufficiency of around 50 genes makes 22q11DS a unique model to investigate the neurobiology underlying stress reactivity in general and in 22q11DS specifically. The current study therefore aims to examine, for the first time, overall cortisol levels, diurnal slope, and cortisol reactivity to daily life stressors using ESM in adults with 22q11DS. Based on previous findings (Jacobson et al., 2016; Sanders et al., 2017), we hypothesize that in their everyday lives, individuals with 22q11DS, will show 1) higher overall cortisol levels, 2) a flatter diurnal slope, and 3) an blunted cortisol response to activity-related stress, when compared to the comparison subjects (HCs).

\section{Method}

\subsection{Sample}

Written informed consent was obtained from all participants who entered the study. Participants were treated in accordance with the Declaration of Helsinki (World Medical Association, 2001). This study was approved by the Medical Ethical Committee of the University of Maastricht (NL). After participation the individuals received a coupon with a total value of 75 euro's for participating in the study. A total of 55 subjects ( $n=3122 q 11 D S$ ) were recruited for the current study. The Dutch (NL) and Flemish (B) individuals with 22q11DS were recruited through the Dutch 22q11DS family network, the National Adult 22q11DS Outpatient Clinic at Maastricht University Medical Centre (NL), the National Children 22q11DS Outpatient Clinic at University Medical Centre Utrecht (NL), and The Center for Human Genetics of the University Hospital Leuven (B). In addition, individuals with 22q11DS who participated in previous studies were approached if they had agreed to be re-contacted. The 22q11DS sample was compared to a sample of $24 \mathrm{HCs}$ partially overlapping with a previous study (Kasanova et al., 2017). Recruitment and inclusion criteria for the HC subjects are the same as described previously (Kasanova et al., 2017).

The general inclusion criteria were: 1) age between 18-60 years, 2) sufficient command of the Dutch language, and 3) mental competence to give informed consent (for the 22q11DS group this was confirmed by an experienced psychiatrist during an interview before inclusion in the study). Additionally, for 22q11DS subjects, there had to be a confirmed deletion at chromosome 22q11.2 (determined by fluorescence in situ hybridization, multiplex ligation-dependent probe amplification, or micro-array analysis). General exclusion criteria were 1) current severe endocrine, cardiovascular, or neurological disease, 2) current alcohol and/or drugs cannabis dependence (confirmed by the substance abuse module of the Composite International Diagnostic Interview (CIDI)) (Robins et al., 1988). Additional exclusion criteria for the HC group in the study were 3) having a lifetime history of Axis I or II disorders as determined by the Mini-International Neuropsychiatric Interview (M.I.N.I.)(Sheehan et al., 1998) and 4) current use of neuroleptics, 
steroids, or thyroid medication.

\subsection{General procedure}

The current study was carried out in two sessions. During the first session participants completed behavioral questionnaires and they were briefed about the cortisol sampling and ESM procedure, and received instructions on how to use the PsyMate ${ }^{\mathrm{TM}}$ (www.psymate.eu) (MyinGermeys et al., 2011), the electronic device used to collect self-assessments. In between the first and the second sessions ESM assessments were collected, with at least two telephone calls from the researchers to verify study compliance. In the second meeting the PsyMate ${ }^{\mathrm{TM}}$ and cortisol samples were recollected, the independent ESM period was debriefed and the final behavioral assessments were finished.

\subsection{Questionnaires / behavioral assessments}

During the first session, demographics and medication use were ascertained. Full scale intelligence quotient (IQ) was assessed for 22q11DS subjects using the shortened version of the Dutch Wechsler Adult Intelligence Scale (WAIS-III-NL) (Canavan et al., 1986; Wechsler, 1997) consisting of four subtests: arithmetic and information (verbal IQ) digit-symbol-coding and block patterns (performance IQ) (Brooks and Weaver, 2005); the Dutch Adult Reading Test (DART) (Schmand et al., 1991) was used to test IQ in the HC group. The 18-item Brief Psychiatric Rating Scale (BPRS) was used to rate general psychopathology (Overall and Gorham, 1962). Within the 22q11DS group, the Mini International Neuropsychiatric Interview (M.I.N.I.) was performed to confirm psychiatric diagnosis (Sheehan et al., 1998). All participants completed the Dutch version of the Childhood Trauma Questionnaire 25-item short form (CTQ) (Bernstein et al., 2003). The questions are rated on a 5-point Likert scale and a general measure of childhood trauma was generated by calculating the sum of the separate domains, including Physical abuse, Emotional abuse, Sexual abuse, Physical neglect, and Emotional neglect.

\subsection{ESM technique and daily stress measure}

ESM is a structured diary method developed to assess participants in their daily life in a natural setting (Delespaul, 1995; Myin-Germeys et al., 2009, 2018). Using the PsyMate ${ }^{\mathrm{TM}}$, participants were signaled with a beep at 10 semi-random times per day on 6 consecutive days between $7: 30 \mathrm{~h}$ and $22: 30 \mathrm{~h}$. After a beep, participants were instructed to fill out a short questionnaire on the PsyMate ${ }^{\mathrm{TM}}$ assessing, among others, their current mood, activity, and context, which were scored on a 7-point Likert scale. The use of the device was explained to the participants in the first briefing session and a test run of the questionnaire was done during which each possible item was explained to the participant and a parent, partner, or supervisor. Participants were excluded if they failed to provide valid responses to at least one third of the beeps and incomplete momentary evaluations were excluded (Myin-Germeys et al., 2001, 2009; Reininghaus et al., 2016). Level of momentary stress was based on the score of two items, rating the appraised stressfulness of the current activity: "I like doing this activity" (reverse coded) and "This activity is difficult for me". These questions were rated on a 7point Likert scale ranging from 1 to $7(1=$ not at all, $7=$ very much $)$. There was a moderate positive correlation between the two items $(r=0.4)$. The mean of these two items was taken to compute the activity-related stress value, with higher scores representing higher levels of activity-related stress. To control for possible confounders, we assessed recent food/drink intake and nicotine and caffeine use since the previous beep using yes/no response options.

\section{5. (Salivary) cortisol}

Saliva samples were collected with every PsyMate ${ }^{\mathrm{TM}}$ beep. After each beep, participants collected a saliva sample using a cotton swab (Salivette, Sarstedt, the Netherlands). They replaced the swab in the tube and recorded the collection time, before storage in their home freezers. During the second meeting the researcher collected the samples and stored the tubes at $-20^{\circ} \mathrm{C}$ until analysis at Dresden University of Technology. Salivary cortisol was analyzed from the saliva samples in duplicate using radio-immunoassays (Dressendörfer et al., 1992). Tracer solution Cortisol 3-CMO coupled with 2-[ $\left[{ }^{125} \mathrm{I}\right]$-histamine and antibodies for Cortisol 3-CMO-BSA was used (Sulon et al., 1978). Cortisol values above $44 \mathrm{nmol} / \mathrm{L}$ were removed from the analyses because they are considered physiologically abnormal (Peeters et al., 2003; Jacobs et al., 2007; Nicolson, 2008; Collip et al., 2011a,b). Cortisol values were log-transformed to reduce skewness of distribution, generating a new additional variable lncort (Collip et al., 2011a,b; Vaessen et al., 2018), which was approximately normally distributed.

\subsection{Statistical analysis}

Statistical analyses were conducted in STATA version 13.1 (StataCorp, College Station, TX, USA; 2013). For all analyses, the level of statistical significance was set to $\alpha=0.05$. Group differences in demographic characteristics, mean scores of all combined (ESM) stress measures, and exposure to childhood trauma were investigated using chi-square tests and analyses of variance (ANOVA). All further analyses were carried out using multilevel regression models, which take into account the hierarchical character of ESM data: momentary observations (level 1) are nested within days (level 2) which are nested within subjects (level 3) (Snijders, 1999). Hence, random effects (intercepts) were added at both the person and day level. We use B to denote the (unstandardized) regression coefficient of a particular predictor in such a multilevel model. To test for group differences in mean cortisol levels over all assessments, a multilevel model was fitted using lncort as the dependent variable and group as the independent variable (Model 1). In this model, the diurnal slope of cortisol was estimated using the variable "centered beep time" (the variable time centered around 15:00 h) and the square of this variable - "centered beep time" $\mathrm{e}^{2}$ as predictors. Centered beep time ${ }^{2}$ did not have a significantly better fit compared to "centered beep time", therefore the model with centered beep time was used, with random slopes for this variable added at person and day level. To further investigate possible differences in diurnal slopes between the groups, the group $\mathrm{x}$ time interaction term was added to the model (Model 2). Finally, to investigate if groups differed in cortisol reactivity to activity-related stressors, activity stress and the group $\mathrm{x}$ activity stress interaction were added as predictors to the model (Model 3) with random slopes for activity stress at the person and day level. In case of a significant interaction effect, the Lincom command was used for comparisons. All models control for age, sex, medication use, oral contraceptive use, recent food and/or drink intake and recent smoking and/or caffeine use. The models also allowed for autocorrelation between residuals within a day (using an AR1 autocorrelation structure), to account for potential autoregressive effects.

\section{Results}

\subsection{Sample (ESM) characteristics}

The 55 participants included ( $n=31$ 22q11DS and $n=24$ HCs) completed 2292 ESM reports and collected 1968 saliva samples. Four 22q11DS participants (with a combined number of 45 valid ESM reports) had to be excluded because they did not provide enough ESM assessments (less than one -third of the total number of beeps (Delespaul, 1995; Myin-Germeys et al., 2011), and 7 cortisol samples of HC participants had to be excluded because they were above the predetermined cut-off (mean cortisol $>44 \mathrm{nmol} / \mathrm{l}$ ). This resulted in a dataset of 1916 valid ESM reports and cortisol samples from 51 subjects, 27 22q11DS patients $(\mathrm{n}=937)$ and 24 HCs $(\mathrm{n}=979)$ (combined $58 \%$ 
Table 1

Demographic characteristics and descriptives.

\begin{tabular}{|c|c|c|c|c|}
\hline & Controls $(n=24)$ & $22 q 11 D S(n=27)$ & Test statistic & $P$ value \\
\hline Sex (n male/n female) & $7 / 17$ & $9 / 18$ & $\mathrm{X}^{2}(1)=0.10$ & 0.75 \\
\hline Age in years, mean (SD) & $39.91( \pm 13.41)$ & $34.11( \pm 9.81)$ & $F=2.16$ & 0.15 \\
\hline $\mathrm{IQ}$, mean (SD) & $106.09( \pm 8.36)$ & $78.29( \pm 10.43)$ & $\mathrm{F}=107.73$ & $<0.001^{* * *}$ \\
\hline Level of education, $\mathbf{n}(\%)$ & & & $X^{2}(2)=24.22$ & $<0.001^{* * *}$ \\
\hline Secondary school or less ${ }^{1}$ & $1(4.17 \%)$ & $14(51.85 \%)$ & & \\
\hline Further education & $8(33.33 \%)$ & $12(44.44 \%)$ & & \\
\hline Higher education & $15(62.50 \%)$ & $1(3.70 \%)$ & & \\
\hline Marital status, n (\%) & & & $\mathrm{X}^{2}(1)=1.2$ & 0.28 \\
\hline Married or living together & $8(33.33 \%)$ & $13(48.15 \%)$ & & \\
\hline Never married / single / divorced & $16(66.67 \%)$ & $14(51.85 \%)$ & & \\
\hline Living situation, n (\%) & & & $\mathrm{X}^{2}(3)=3.4$ & 0.33 \\
\hline Alone & $6(25.00 \%)$ & $4(14.81 \%)$ & & \\
\hline With parents / relatives & $11(45.83 \%)$ & $13(48.15 \%)$ & & \\
\hline With partner/family/children/alone with children & $7(29.17 \%)$ & $7(25.93 \%)$ & & \\
\hline Special housing (psychiatric/non-psychiatric institute) & $0(0 \%)$ & $3(11.11 \%)$ & & \\
\hline Source of income, $\mathbf{n}(\%)$ & & & $X^{2}(2)=6.7$ & $0.03^{*}$ \\
\hline Salary (work) / student fee & $18(75.00 \%)$ & $11(40.74 \%)$ & & \\
\hline Income from social workplace & $0(0 \%)$ & $2(7.41 \%)$ & & \\
\hline Income from benefit or maintenance ${ }^{2}$ & $6(25.00 \%)$ & $14(51.85 \%)$ & & \\
\hline Work situation, n (\%) & & & $\mathrm{X}^{2}(1)=3.8$ & 0.05 \\
\hline Working / significant housework / studying & $18(75.00 \%)$ & $13(48.15 \%)$ & & \\
\hline Disabled or unemployed & $6(25.00 \%)$ & $14(51.85 \%)$ & & \\
\hline Childhood Trauma Questionnaire (CTQ), mean (SD) $(H C n=24,22 q n=26)$ & $34.08( \pm 7.62)$ & $33.73( \pm 8.99)$ & $\mathrm{F}=0.02$ & 0.88 \\
\hline \multicolumn{5}{|l|}{ ESM, mean (SD) $(H C n=979,22 q n=937)$} \\
\hline Mean Momentary Cortisol in $\mathrm{nmol} / \mathrm{l}$ & $9.97(3.08)$ & $3.62(1.34)$ & $\mathrm{F}=94.18$ & $<0.001^{*}$ \\
\hline Number of beeps filled out per participant & $46.79( \pm 7.92)$ & $41.62( \pm 8.73)$ & $\mathrm{F}=4.84$ & $0.03^{*}$ \\
\hline Momentary activity stress & $2.68( \pm 0.69)$ & $2.60( \pm 1.03)$ & $\mathrm{F}=0.11$ & 0.74 \\
\hline Momentary caffeine use & $0.29( \pm 0.21)$ & $0.23( \pm 0.20)$ & $\mathrm{F}=1.17$ & 0.29 \\
\hline Momentary nicotine use & $0.09( \pm 0.24)$ & $0.09( \pm 0.26)$ & $\mathrm{F}=0.01$ & 0.93 \\
\hline BPRS total, mean (SD) & $18.46( \pm 4.30)$ & $22.93( \pm 5.30)$ & $\mathrm{F}=10.75$ & $0.002^{\text {kn }}$ \\
\hline \multicolumn{5}{|l|}{ Diagnosis (M.I.N.I.), n (\%) } \\
\hline Psychotic disorder & $0(0 \%)$ & $1(3.7 \%)$ & & \\
\hline Mood (and Anxiety) disorder & $0(0 \%)$ & $4(14.8 \%)$ & & \\
\hline Only Anxiety disorder & $0(0 \%)$ & $3(11.11 \%)$ & & \\
\hline None & $24(100 \%)$ & $19(70.4 \%)$ & & \\
\hline Oral contraceptive, $\mathbf{n}(\%)$ & $0(0 \%)$ & $2(7.41 \%)$ & $X^{2}(1)=1.85$ & 0.17 \\
\hline Medication $^{3}$, n (\%) & $0(0 \%)$ & $14(51.85 \%)^{3}$ & $X^{2}(1)=14.67$ & $<0.001^{* * *}$ \\
\hline
\end{tabular}

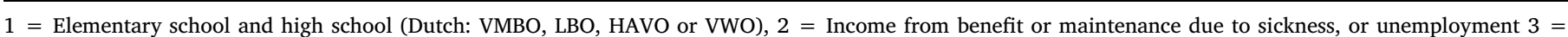

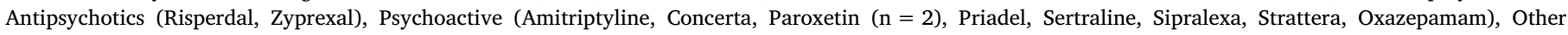
medication (Betamethason, Flixonase, Omeprazol).

$* \mathrm{p}<0.05$.

$* * \mathrm{p}<0.001$.

Table 2

Results from multilevel linear regression analyses of the effects of cortisol reactivity between groups (Model 1), in the interaction of group and time (Model 2), and in the interaction of group and activity related stress (Model 3).

\begin{tabular}{|c|c|c|c|c|c|c|c|c|c|c|c|c|}
\hline \multirow[t]{2}{*}{ ln Cortisol } & \multicolumn{4}{|c|}{ Model 1 - Group } & \multicolumn{4}{|c|}{ Model 2 - Time } & \multicolumn{4}{|c|}{ Model 3 - Activity Stress } \\
\hline & B & S.E. & 95\% C.I. & $\mathrm{p}$ & B & S.E. & 95\% C.I. & $\mathrm{p}$ & B & S.E. & 95\% C.I. & $\mathrm{p}$ \\
\hline Group (HC vs 22q11DS) & -1.036 & 0.109 & $\begin{array}{l}-1.24<-> \\
-0.82\end{array}$ & $<0.001^{* *}$ & -1.032 & 0.110 & $\begin{array}{l}-1.24<-> \\
-0.82\end{array}$ & $<0.001^{* *}$ & -0.920 & 0.120 & $\begin{array}{l}-1.15<-> \\
-0.69\end{array}$ & $<0.001^{* * *}$ \\
\hline Time & -0.134 & 0.006 & $\begin{array}{l}-0.15<-> \\
-0.12\end{array}$ & $<0.001^{k *}$ & -0.137 & 0.009 & $\begin{array}{l}-0.15<-> \\
-0.12\end{array}$ & $<0.001^{* * *}$ & -0.134 & 0.006 & $\begin{array}{l}-0.15<-> \\
-0.12\end{array}$ & $<0.001^{* *}$ \\
\hline Group $x$ Time & $\mathrm{x}$ & $\mathrm{x}$ & & $\mathrm{x}$ & 0.006 & 0.012 & $\begin{array}{l}-0.02<-> \\
-0.03\end{array}$ & 0.631 & $\mathrm{X}$ & $\mathrm{X}$ & & $\mathrm{x}$ \\
\hline Activity related Stress & $\mathrm{x}$ & $\mathrm{x}$ & & $\mathrm{x}$ & $\mathrm{x}$ & $\mathrm{x}$ & & $\mathrm{x}$ & 0.026 & 0.013 & $\begin{array}{l}-0.00<-> \\
-0.05\end{array}$ & 0.051 \\
\hline $\begin{array}{l}\text { Group x Activity } \\
\text { related Stress }\end{array}$ & $\mathrm{x}$ & $\mathrm{x}$ & & $\mathrm{x}$ & $\mathrm{x}$ & $\mathrm{x}$ & & $\mathrm{x}$ & -0.044 & 0.020 & $\begin{array}{l}-0.08<-> \\
-0.01\end{array}$ & $0.026^{*}$ \\
\hline
\end{tabular}

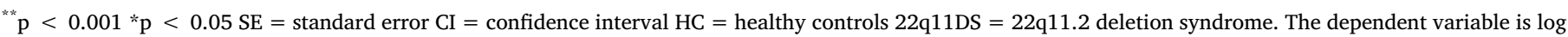

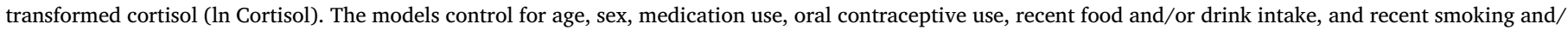

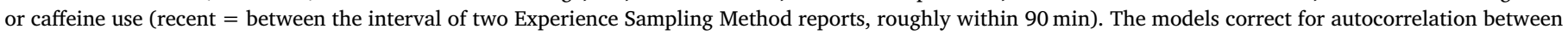
residuals.

compliance). Demographics of included participants are shown in Table 1. Groups did not differ on most demographic characteristics, but there were significant group differences in level of education, source of income, mean BPRS score, medication use, and compliance (Table 1). As expected, given that impaired cognitive function is a core characteristic of individuals with 22q11DS (Jonas et al., 2014; Schneider et al., 2014; Yi et al., 2016), IQ was significantly lower in 22q11DS individuals compared to HCs $(\mathrm{F}(1,49)=107.73$, $\mathrm{p}<0.001$, Table 1). CTQ scores did not differ between the 22q11DS and HC groups. 


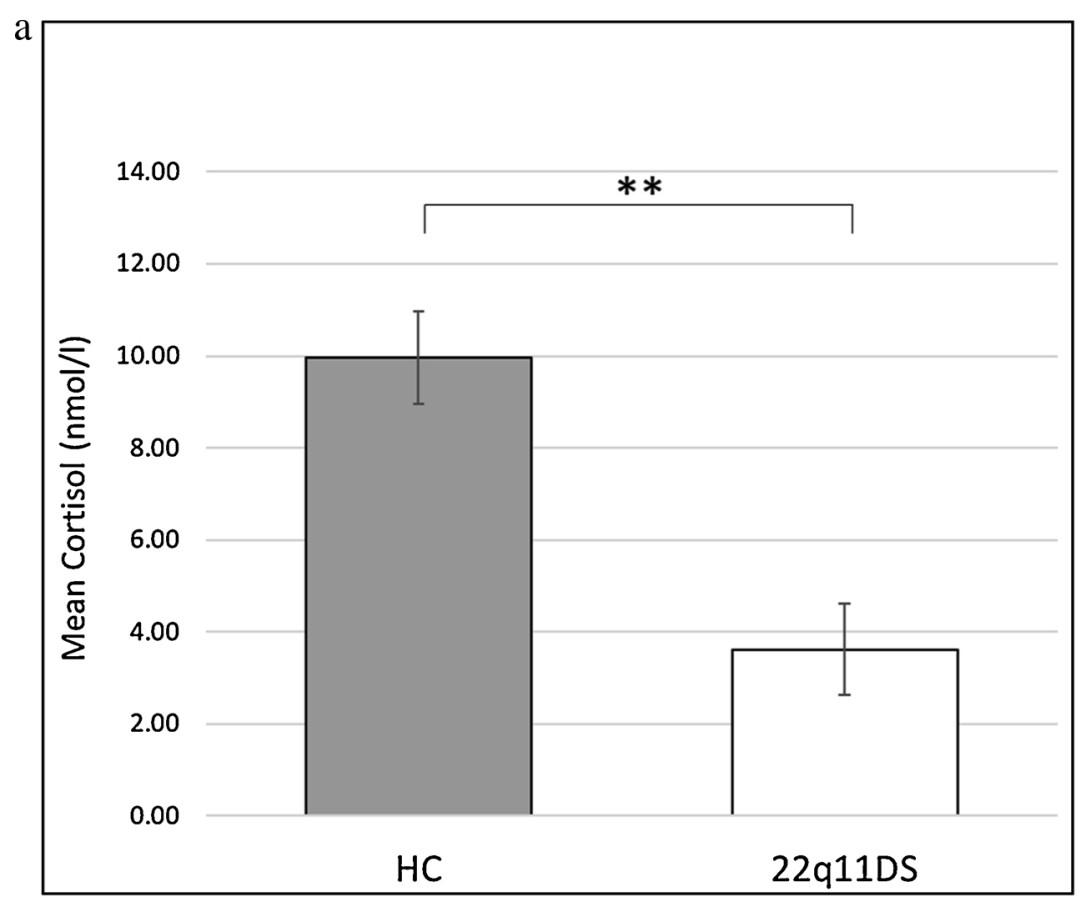

Fig. 1. (a) Mean Cortisol differences including standard error bars, between healthy controls $(\mathrm{HC})(\mathrm{n}=24)$ and the 22q11.2 deletion syndrome (22q11DS) group $(n=27)$. $* *=\mathrm{p}<0.001$.(b) Mean Cortisol differences between healthy controls ( $\mathrm{HC} ; \mathrm{n}=24$ ) and the 22q11.2 deletion syndrome $(22 \mathrm{q} 11 \mathrm{DS})$ group $(\mathrm{n}=27)$. Modelled change (based on regression coefficient) in untransformed cortisol values (nmol/l) over time of the day (in hours). Both groups have a significant reduction in mean cortisol over the day (significant main effect of time of the day: $\mathrm{B}=-0.14, \mathrm{SE}=0.009, \mathrm{p}<0.001$; not significant interaction effect of group $\mathrm{x}$ time: $\mathrm{B}=0.006, \mathrm{SE}=0.012$, $\mathrm{p}=0.63) .22 \mathrm{q} 11 \mathrm{DS}$ have a significant lower cortisol diurnal slope compared to HC (see Table 2 for statistics).

b

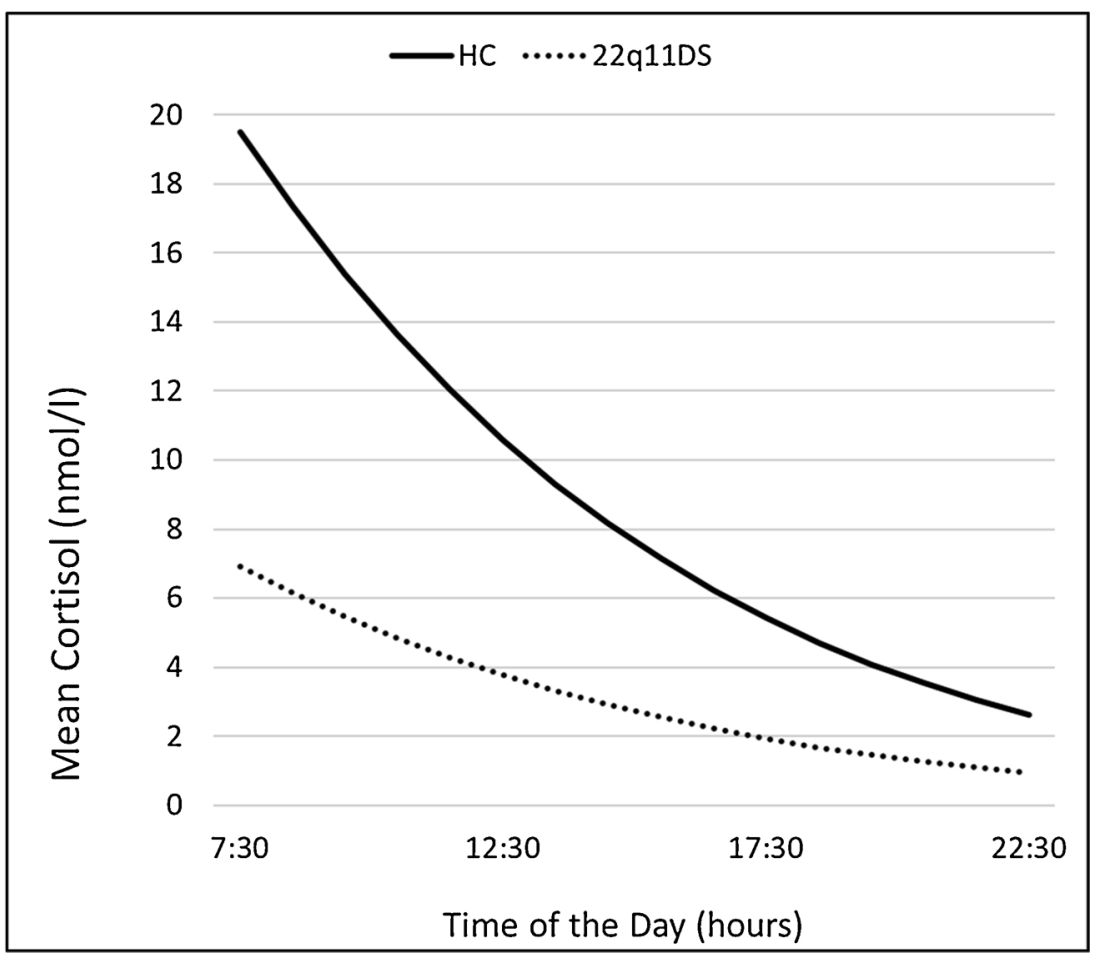

\subsection{Cortisol levels and diurnal slope}

Mean cortisol levels of all the combined samples were significantly lower in 22q11DS participants compared to HC $(F(1,49)=94.18$, $\mathrm{p}<0.001$ Table 1, Fig. 1a). Moreover, multilevel linear regression analyses revealed that 22q11DS participants had significantly lower cortisol levels across all ESM sampling moments compared to HCs ( $\mathrm{B}=$ 1.03, $\mathrm{p}<0.001$; Figure 1 \& Table 2). There was a significant effect of time on mean cortisol, showing a significant cortisol decline during the day, with higher cortisol levels in the morning compared to the evening
( $\mathrm{B}=-0.13, \mathrm{p}<0.001$, Fig. 1 \& Table 2). There was no significant interaction between time and group, suggesting a comparable steepness of the diurnal decline in cortisol throughout the day between groups ( $\mathrm{B}=0.01, \mathrm{p}=0.63$, Fig. 1 \& Table 2).

\subsection{Cortisol reactivity to daily stressors}

There was no significant difference in mean activity-stress between the groups (Table 1). Multilevel linear regression analyses revealed that cortisol reactivity to activity-related stress differed significantly 


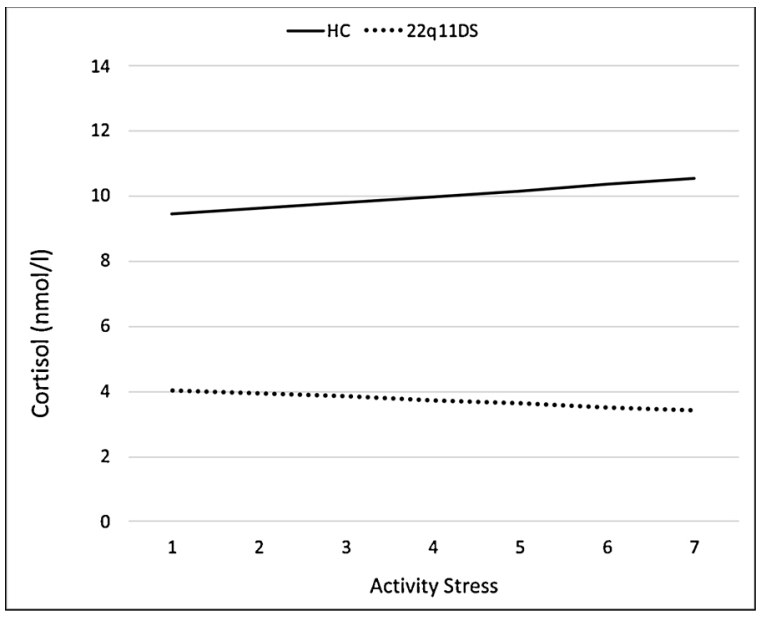

Fig. 2. Cortisol reactivity to recent stressful activities, in 22q11.2 deletion syndrome (22q11DS; $n=27$ ) versus healthy controls (HCs; $n=24$ ). Modelled change (based on regression coefficient) in untransformed cortisol values (nmol/l) following daily activity stress (within $90 \mathrm{~min}$ ). 22q11DS have a significant different cortisol reactivity compared to HC (see Table 2 for statistics). Activity stress was based on the average score of 2 ESM items (See Table 1).

between the 22q11DS and HC group $(B=-0.044 p=0.026$, Fig. $2 \&$ Table 2). Whereas in the HC group higher activity related stress seems to be associated with increased cortisol levels, this cortisol response seems to be blunted in the 22q11DS group (Fig. 2). Activity-related stress was trend significantly associated with cortisol reactivity within the HC group ( $\mathrm{B}=0.03, \mathrm{SE}=0.01,95 \% \mathrm{CI}-0.00$ to $0.05, \mathrm{p}=0.051$ ). Activity-related stress was not significantly associated with cortisol reactivity within the 22q11DS group $(B=-0.02, S E=0.01,95 \%$ CI -0.05 to $0.01, p=0.22$ ). The conclusions did not significantly change after the inclusion of levels of education and income as a covariate.

\subsection{Post-hoc analyses}

To further explore the differences between individuals with 22q11DS and HCs, we tested several post-hoc hypotheses to explain the results described above.

First, we tested the hypothesis that the alterations found in 22q11DS individuals are associated with higher levels of symptoms indicative of psychopathology (BPRS) or cognitive disabilities (IQ). We included BPRS total scores and IQ scores as predictors in the multilevel regression models. These analyses suggested that neither were significantly related to cortisol and inclusion of these variables did not alter the main conclusions and majority of the previous findings. Only a minor change of significance emerged in the analyses controlling for BPRS, marking activity stress significantly associated with cortisol in the HC group ( $\mathrm{B}=0.03 \mathrm{SD}=0.01395 \% \mathrm{CI} 0.00-0.05 \mathrm{p}=0.044)$, where it was previously only trend significant (Table 2 ).

Second, we added CTQ as covariate to the models to test the hypothesis that the between-group differences we observed resulted from chronic alterations due to exposure to (childhood) traumatic events. CTQ score was not associated with our stress measures (cortisol and activity-related stress), and the initial findings remained the same.

Finally, we investigated whether the results could be explained by the effect of medication or M.I.N.I. diagnosis present in the 22q11DS group. To this end, we repeated our main analysis comparing the 22q11DS group with the HC group with exclusion of participants who were using medication (22q11DS $n=14$ ) and additional analysis excluding the participants with a M.I.N.I. diagnosis (22q11DS $n=8$ ), but the conclusions remained unchanged.

\section{Discussion}

Here we report results from the first study to investigate cortisol levels and cortisol stress reactivity using the ESM method in adults with 22q11DS, a genetically defined population at increased risk for developing psychiatric disorders. Our main findings suggest that individuals with 22q11DS show overall lower mean cortisol levels and blunted cortisol reactivity to activity-related stress compared to HCs. This suggests that alterations in HPA-axis functioning, previously reported in several psychiatric disorders including post-traumatic stress disorder (PTSD), psychotic disorder, and mood disorder, thus also appear to be present in adults with 22q11DS.

\subsection{Overall cortisol \& diurnal slope}

We found lower mean cortisol levels in 22q11DS, in line with findings in non-clinical populations including people with temperamental shyness and social anxiety (Beaton et al., 2006, 2013) and findings in patient groups suffering from long term exposure to stress (Fries et al., 2005), such as PTSD (Yehuda et al., 1996), atypical depression (Gold and Chrousos, 2002; Van Hoof et al., 2003), chronic fatigue syndrome (Van Hoof et al., 2003; Roberts et al., 2004), and burn-out (Pruessner et al., 1999). Our cortisol findings in adults with 22q11DS are in contrast to findings in children with 22q11DS, where elevated cortisol levels were previously found (Jacobson et al., 2016; Sanders et al., 2017). This may be explained by chronic overactivation of the HPA-axis (i.e., allostatic load), suggested to lead to a stronger, or overly sensitive, negative feedback response by cortisol, eventually resulting in lower cortisol levels, as suggested in PTSD (Yehuda et al., 1996; Yehuda, 2002; Daskalakis et al., 2013). Both groups were found to have no difference in CTQ scores, however, which was also not associated with cortisol in our analyses, thus challenging this explanation. However, sensitization of the stress system could occur in the absence of major traumatic events, for instance in response to the lifelong dayto-day stressful challenges associated with the syndrome (Swillen et al., 1999; Beaton and Simon, 2011). Minor daily life challenges (or unexpected events) might additionally be experienced more stressful (traumatic), potentially associated to the high levels of chronic stress and anxiety in (children with) 22q11DS (Swillen et al., 1999; Beaton and Simon, 2011; Phillips et al., 2017; Vo et al., 2018). Future studies should take these topics into account when investigating cortisol in 22q11DS before any definite conclusions on the role of chronic stress can be drawn.

The steepness of the diurnal decline in cortisol throughout the day did not differ between the groups, and although in contrast with our initial hypothesis, this result is in line with previous studies comparing HCs with relatives of psychotic patients (Collip et al., 2011a,b) and individuals with schizophrenia (Jansen et al., 2000). This indicates that the diurnal slope abnormalities do not necessarily have to be expected in individuals with stress-related symptoms.

Moreover, no significant effects of age, sex, IQ, and psychopathology symptom scores on cortisol levels were found. Interestingly, the lower cortisol levels compared to HC remained after excluding 22q11DS participants with a psychiatric diagnosis or medication use. This indicates that the reported lower cortisol levels found in the 22q11DS group are present irrespective of sex, age, and psychopathological factors, pointing towards alternative mechanisms that may better explain our findings, as is discussed below.

\subsection{Cortisol reactivity to activity-related stress}

Lower cortisol levels in 22q11DS, combined with previous findings indicating high levels of chronic stress in (infancy in) 22q11DS (Beaton and Simon, 2011), suggest an abnormal biological reactivity (possibly related to haploinsufficiency of 22q11.2 genes) to stressful situations. 
Interestingly, we also found a differential pattern of cortisol stress-reactivity in the 22q11DS group compared to HCs which is in line with our hypothesis. These findings should be interpreted with caution, however, since the activity-related stress was trend significantly (positively) associated with cortisol in the HC group, and the negative association in the 22q11DS group failed to reach significance.

The results indicate that 22q11DS seems to have a blunted cortisol response to activity-related stress, consistent with some studies in psychotic disorder (Zorn et al., 2017; Vaessen et al., 2018), individuals at ultra-high risk for psychosis (Pruessner et al., 2013)first episode psychosis (van Venrooij et al., 2012) and females with major depressive and anxiety disorders ${ }^{19}$. In 22q11DS, sensitization of the HPA-axis could lead to a dissociation between the endocrinological stress response and the daily (minor) activity-related stress (Yehuda et al., 1996). This notion is supported by a study showing no effect of suppressing HPA-axis activity in HCs on subjective stress reports, indicating that the emotional stress experienced remained intact even when the HPA-axis response was suppressed (Ali et al., 2017).

However, we did not find any effect of psychotic symptomatology on cortisol stress reactivity, indicating that the cortisol reactivity abnormalities are present in 22q11DS individuals regardless of psychiatric symptoms. Moreover, we did not find higher childhood trauma scores, nor an effect of childhood trauma on cortisol reactivity in 22q11DS individuals, which was expected based on previous research suggesting a role for childhood related stress in the etiophathology of psychiatric symptoms in individuals with 22q11DS (Beaton and Simon, 2011).

To summarize, psychological mechanisms in individuals with 22q11DS related to stress, such as psychopathology, do not appear to be plausible explanations for our findings. The 22q11DS has unique genetic characteristics, suggesting that the observed results could be explained by the biological mechanisms associated with 22q11DS.

\subsection{Biological mechanisms}

There are several possible underlying biological mechanisms causing the suggested lower cortisol levels and blunted cortisol stress reactivity found in adults with 22q11DS. Research from twin studies established that genetic factors account for a significant portion of the variation in HPA-axis functioning (Tucker-Drob et al., 2017). A possible explanation could therefore be the haploinsufficiency for genes in the deleted region, suggested to be related to the increased risk for developing psychiatric disorders in 22q11DS individuals (Boot et al., 2011; Gothelf et al., 2014). Hemizygosity of the proline (dehydrogenase) oxidase 1 gene (PRODH), encoding the enzyme that catalyzes the conversion of proline to glutamate and has effects on the NMDA receptor (Ferreira et al., 2012, no date), could potentially be related to aberrant stress-reactivity in 22q11DS because glutamate and the NMDA receptor are implicated to play an important role in the regulation of the HPA axis (Mathew et al., 2001).

Another gene in the deleted region of 22q11DS, the Catechol-Omethyltransferase (COMT) gene, encoding the enzyme that breaks down especially frontal noradrenaline (NA) and dopamine (DA), is additionally suggested to alter HPA-axis functioning (Oswald et al., 2004). The COMT Met-allele results in lower COMT activity compared to the Val-allele (Chen et al., 2004), and reduced COMT activity as a result of hemizygosity is present in individuals with 22q11DS (Gothelf et al., 2014). Especially low COMT activity, probably resulting in higher levels of NA and DA, is associated with increased sensitivity to (early life) stress and cortisol reactivity in healthy adults (Oswald et al., 2004; Van Winkel et al., 2008; Collip et al., 2011; Lovallo et al., 2017).

Although cortisol levels are elevated in children with 22q11DS (Jacobson et al., 2016; Sanders et al., 2017), we found lower cortisol levels in adults with 22q11DS, indicating impairments in the developmental trajectory of the endocrine systems. This is in line with recent insights from a longitudinal study in HCs showing that "short term" physiological symptoms in children were associated with hypercortisolism, while chronic worry and social concerns predicted lower cortisol levels 3 years later (Ma et al., 2018). A similar developmental trajectory, involving over-activation, over-sensitization, or some sort of exhaustion of the endocrine or signaling systems over the years, was previously suggested for DA in 22q11DS (Boot et al., 2008a,b). Also, a hyperdopaminergic state is found to be present in adolescents and adults with 22q11DS (Boot et al., 2008a,b; van Duin et al., 2017) whereas later in life 22q11DS individuals have an increased risk for developing early-onset Parkinson's disease, associated with striatal hypodopaminergia (Booij et al., 2010). We can only speculate about potential endophenotypes related to this suggested impairment in the developmental trajectory. As suggested in previous research, lower cortisol levels might reflect a life history of coping with social anxiety (Beaton et al., 2013). A 22q11.2 deletion could perhaps also severely disrupt neurotransmission in the catecholaminergic and endocrine systems over time. Impairments in the DA and cortisol systems may be important factors associated with increased risk for mental disorders in individuals with 22q11DS.

To summarize, the abnormalities in cortisol reactivity and lower cortisol levels found in our study could potentially be explained by genetically determined abnormalities of the stress system and aberrant developmental trajectories in 22q11DS. Future research is necessary to shed light on the potential role of these mechanisms in stress reactivity and its mediating role in the increased risk of developing psychiatric and neurological problems.

\subsection{Clinical implications}

One might speculate how the lower cortisol levels and abnormal cortisol stress reactivity relate to the multisystem clinical features in adults with 22q11DS. Abnormal HPA-axis functioning was previously found to be related to psychotic disorders (Collip et al., 2011a,b; Zorn et al., 2017), major depressive disorder (Yehuda et al., 1996), PTSD (Yehuda, 2002; Daskalakis et al., 2013), and other anxiety disorders (Zorn et al., 2017). Hence, it is therefore likely to be related to psychiatric problems in individuals with 22q11DS as well (prevalence \pm $60 \%$, adults)(Bassett et al., 2011). This suggestion is in line with recent research confirming the role of stress and coping in the pathway to psychosis in individuals with 22q11DS (Armando et al., 2018). The biologically inherited abnormal HPA-axis functioning could perhaps precede psychopathology in 22q11DS, despite the fact that we did not find this in the current study, including 22q11DS individuals with no or minor psychiatric problems.

The lower cortisol levels in adults with 22q11DS could also be related to the high rates of immunological deficiencies, abnormal functioning of the endocrine system, and metabolic disorders in the 22q11DS (Bassett et al., 2005; Shprintzen, 2008; Fung et al., 2015). These disorders in 22q11DS include, amongst others, obesity (35\%, adults), autoimmune diseases, hypocalcemia ( $>60 \%$, attributable to hypoparathyroidism), and related (psychosomatic) symptoms like fatigue and emotional irritability (Mcdonald-Mcginn et al., 2015; Scandurra et al., 2013; Vergaelen et al., 2017). Our results on altered cortisol functioning add valuable new evidence for the endocrine impairments in individuals with 22q11DS. More research would therefore be necessary to further investigate the exact association between cortisol levels and the clinical multisystem features in 22q11DS.

\subsection{Strengths, limitations and future directions}

With this study we investigated cortisol stress reactivity in a unique sample of adult individuals with 22q11DS for the first time, using the well-validated ESM method (Myin-Germeys et al., 2009). It is important to note several limitations to our methods, however. First, the high number of 22q11DS participants that had to be excluded from the final analyses based on the generally accepted exclusion criteria (compliance to ESM protocol of $<33 \%$ (Delespaul, 1995)) and the significantly 
lower number of assessments filled out by the 22q11DS group (Table 1) could imply that the diary method in its current form is not appropriate for this patient group. Although previous studies using ESM demonstrated the feasibility and reliability of this method in vulnerable populations (Delespaul, 1995; Myin-Germeys et al., 2000; Shiffman et al., 2008; Myin-Germeys et al., 2009), future research should consider the vulnerability of the population and possible deviations in compliance rate in the design of the protocol and the PsyMate ${ }^{\mathrm{TM}}$ questions.

Second, although the activity-stress item has previously been used in comparable studies (Jacobs et al., 2007; Vaessen et al., 2018), it is important to note that in the current study, "activity stress" was defined using only two questions, possibly not reliably representing all categories of current daily stressors. Short-lived stressful moments, such as daily hassles, could for instance occur in between two assessment periods, and may not be captured by the momentary assessment protocol used. Third, several factors, such as physical activity, that can influence cortisol levels (Miller et al., 2007; Nicolson, 2008) were not taken into account in the current ESM protocol. Future investigation may incorporate these measures.

Fourthly, as mentioned before, it is possible that the retrospective and momentary questionnaires used were not capturing the currentand childhood stressors, concealing potential associations between cortisol and childhood trauma or psychopathology in our sample. Future research may include more comprehensive assessment tools for psychopathology, affect, anxiety, and (chronic childhood) stress-related symptoms.

Finally, it should be noted that the sample of 22q11DS participants was heterogenous in their psychopathological profile and medication use, despite that the majority comprised of relatively high functioning patients (in terms of daily life functioning). This could potentially explain the absence of significant associations between chronic childhood stress, psychopathology, and cortisol. Research in a larger sample including more patients with (mild) psychiatric symptoms with 22q11DS will enable the possibility to create (more) homogenous clinical subgroups, which may provide additional insight in the association between psychopathology and cortisol stress-reactivity and possible causal factors like childhood trauma.

\section{Conclusion}

The current report demonstrates, for the first time, lower overall cortisol levels in adults with 22q11DS and attenuated cortisol response to daily stress, independent of medication use and psychiatric diagnosis. This could potentially be related to hemizygosity of genes located on 22q11.2 and could imply a permanent long-term effect of chronic stress.

\section{Financial support}

This work was supported by an ERC consolidator grant to Prof. Dr. Inez Myin-Germeys (ERC- 2012-StG, project 309767 - INTERACT) and the National Institute of Mental Health of the National Institutes of Health under Award Number U01MH101722.

\section{Conflict of interest}

None.

\section{Acknowledgements}

We like to thank the participants, their families and "stichting Steun 22q11". The authors additionally thank Debora op "t Eijnde, Nele Soons, Wendy Beuken, Merrit Beck, India Teunissen, Justine Lamee, Lucas Lumeij, Dirk Koster, Gijs Oosting, Jytte Huijstee, Uli Reininghaus, Yousseff El Bouhassani, Elfi Vergaelen, Ania Fiksinski, Sasja Duijff, Lara Janssen and Ron Mengelers for their assistance in data collection, analysis and management.

\section{References}

Adam, E.K., Quinn, M.E., Tavernier, R., McQuillan, M.T, Dahlke, K.A., Gilbert, K.E. 2017. Diurnal cortisol slopes and mental and physical health outcomes: a systematic review and meta-analysis. Psychoneuroendocrinology 83, 25-41.

Ali, N., Nitschke, J.P., Cooperman, C., Pruessner, J.C., 2017. Suppressing the endocrine and autonomic stress systems does not impact the emotional stress experience after psychosocial stress. Elsevier. Psychoneuroendocrinology 78, 125-130.

Andersen, S.L., Tomada, A., Vincow, E.S., Valente, E., Polcari, A., Teicher, M.H., 2008. Preliminary evidence for sensitive periods in the effect of childhood sexual abuse on regional brain development. J. Neuropsychiatry Clin. Neurosci. 20, 292-301.

Armando, M., Sandini, C., Chambaz, M., Schaer, M., Schneider, M., Eliez, S., 2018. Coping strategies mediate the effect of stressful life events on schizotypal traits and psychotic symptoms in 22q11. 2 deletion syndrome. Schizophr. Bull. 44 (suppl. 2), S525-S535.

Bassett, A.S., Chow, E.W.C., Husted, J., Weksberg, R., Caluseriu, O., Webb, G.D., Gatzoulis, Ma., 2005. Clinical features of 78 adults with 22q11 deletion syndrome. Am. J. Med. Genet. 138 A, 307-313.

Bassett, A.S., McDonald-McGinn, D.M., Devriendt, K., Digilio, M.C., Goldenberg, P. Habel, A., Marino, B., Oskarsdottir, S., Philip, N., Sullivan, K., Swillen, A., Vorstman, J., 2011. Practical guidelines for managing patients with 22q11.2 deletion syndrome. J. Pediatr. 159, 332-339 e1.

Beaton, E.A., Simon, T.J., 2011. How might stress contribute to increased risk for schizophrenia in children with chromosome 22q11.2 deletion syndrome? BioMed Central J. Neurodev. Disord. 3, 68-75.

Beaton, E.A., Schmidt, L.A., Ashbaugh, A.R., Santesso, D.L., Antony, M.M., McCabe, R.E., Segalowitz, S.J., Schulkin, J., 2006. Low salivary cortisol levels among socially anxious young adults: preliminary evidence from a selected and a non-selected sample. Pers. Individ. Dif. 41 (7), 1217-1228.

Beaton, E.A., Schmidt, L.A., Schulkin, J., Hall, G.B., 2013. Repeated measurement of salivary cortisol within and across days among shy young adults. Pers. Individ. Dif. 55 (6), 705-710.

Bernstein, D.P., Stein, J.A., Newcomb, M.D., Walker, E., Pogge, D., Ahluvalia, T., Stokes, J., Handelsman, L., Medrano, M., Desmond, D., Zule, W., 2003. Development and validation of a brief screening version of the Childhood Trauma Questionnaire. Pergamon Child Abuse Neglect. 27, 169-190.

Bolger, N., Davis, A., Rafaeli, E., 2003. Diary methods: capturing life as it is lived. Annu. Rev. Psychol. 54, 579-616.

Booij, J., Van Amelsvoort, T., Boot, E., 2010. Co-occurrence of early-onset Parkinson disease and 22q11.2 deletion syndrome: potential role for dopamine transporter imaging. Am. J. Med. Genet. A 152, 2937-2938.

Boot, E., Booij, J., Zinkstok, J., Abeling, N., de Haan, L., Baas, F., Linszen, D., van Amelsvoort, T., 2008a. Disrupted dopaminergic neurotransmission in 22q11 deletion syndrome. Neuropsychopharmacology 33, 1252-1258.

Boot, E., Booij, J., Zinkstok, J., Abeling, N., de Haan, L., Baas, F., Linszen, D., van Amelsvoort, T., 2008b. Disrupted dopaminergic neurotransmission in 22q11 deletion syndrome. Neuropsychopharmacology 33, 1252-1258.

Boot, E., Booij, J., Zinkstok, J.R., Baas, F., Swillen, A., Owen, M.J., Murphy, D.G., Murphy, K.C., Linszen, D.H., Van Amelsvoort, T., 2011. COMT Val158met genotype and striatal D2/3 receptor binding in adults with 22 q11 deletion syndrome. Synapse 65, 967-970.

Brooks, B.L., Weaver, L.E., 2005. Concurrent validity of WAIS-III short forms in a geriatric sample with suspected dementia: verbal, performance and full scale IQ scores. Arch. Clin. Neuropsychol. 20, 1043-1051.

Canavan, A.G.M., Dunn, G., McMillan, T.M., 1986. Principal components of the WAIS-R. Br. J. Clin. Psychol. 25, 81-85.

Carotti, A., Digilio, M.C., Piacentini, G., Saffirio, C., Di Donato, R.M., Marino, B., 2008. Cardiac Defects and Results of Cardiac Surgery in 22q11.2 Deletion Syndrome 14. Wiley-Blackwell Developmental Disabilities Research Reviews, pp. 35-42.

Chen, J., Lipska, B.K., Halim, N., Ma, Q.D., Matsumoto, M., Melhem, S., Kolachana, B.S., Hyde, T.M., Herman, M.M., Apud, J., Egan, M.F., Kleinman, J.E., Weinberger, D.R., 2004. Functional analysis of genetic variation in catechol-O-methyltransferase (COMT): effects on mRNA, protein, and enzyme activity in postmortem human brain. Am. J. Hum. Genet. 75, 807-821.

Collip, D., Nicolson, N.A., Lardinois, M., Lataster, T., Van Os, J., Myin-Germeys, I., 2011a. Daily cortisol, stress reactivity and psychotic experiences in individuals at above average genetic risk for psychosis. Psychol. Med. 41, 2305-2315.

Collip, D., van Winkel, R., Peerbooms, O., Lataster, T., Thewissen, V., Lardinois, M., Drukker, M., Rutten, B.P.F., Van Os, J., Myin-Germeys, I., 2011b. COMT Val158MetStress Interaction in Psychosis: Role of Background Psychosis Risk 17. Wiley/ Blackwell (10.1111) CNS Neuroscience \& Therapeutics, pp. 612-619.

Corcoran, C., Walker, E., Huot, R., Mittal, V., Tessner, K., Kestler, L., Malaspina, D., 2003. The stress cascade and schizophrenia:etiology and onset. Schizophr. Bull. 29, $671-692$.

Daskalakis, N.P., Lehrner, A., Yehuda, R., 2013. Endocrine aspects of post-traumatic stress disorder and implications for diagnosis and treatment. Elsevier Inc. Endocrinol. Metab. Clin. North Am. 42, 503-513.

De Bellis, M.D., Zisk, A., 2014. The biological effects of childhood trauma. Elsevier. Child Adolesc. Psychiatr. Clin. N. Am. 23, 185-222 vii.

Delespaul, P., 1995. Assessing Schizophrenia in Daily Life : The Experience Sampling Method. University of Maastricht.

Dressendörfer, R.A., Kirschbaum, C., Rohde, W., Stahl, F., Strasburger, C.J., 1992 Synthesis of a cortisol-biotin conjugate and evaluation as a tracer in an immunoassay for salivary cortisol measurement. Pergamon. J. Steroid Biochem. Mol. Biol. 43, 683-692.

Ferreira, A.G.K., da Cunha, A.A., Scherer, E.B., Machado, F.R., da Cunha, M.J., Braga, A., 
Mussulini, B.H., Moreira, J.D., Wofchuk, S., Souza, D.O., Wyse, A.T., 2012. Evidence that hyperprolinemia alters glutamatergic homeostasis in rat brain: neuroprotector effect of Guanosine. Neurochem. Res. 37, 205-213.

Fries, E., Hesse, J., Hellhammer, J., Hellhammer, D.H., 2005. A new view on hypocortisolism. Pergamon Psychoneuroendocrinol. 30, 1010-1016.

Fung, W.L.A., Butcher, N.J., Costain, G., Andrade, D.M., Boot, E., Chow, E.W.C., Chung, B., Cytrynbaum, C., Faghfoury, H., Fishman, L., García-miñaúr, S., George, S., 2015. Practical guidelines for managing adults with 22q11.2 deletion syndrome. Genet. Med. 17, 599.

Gold, P.W., Chrousos, G.P., 2002. Organization of the stress system and its dysregulation in melancholic and atypical depression: high vs low CRH/NE states. Nature Publishing Group. Mol. Psychiatry 7, 254-275.

Gothelf, D., Law, A.J., Frisch, A., Chen, J., Zarchi, O., Michaelovsky, E., Ren-Patterson, R., Lipska, B.K., Carmel, M., Kolachana, B., Weizman, A., Weinberger, D.R., 2014. Biological effects of COMT haplotypes and psychosis risk in 22q11.2 deletion syndrome. Elsevier Biological Psychiatry 75, 406-413.

Green, T., Gothelf, D., Glaser, B., Debbane, M., Frisch, A., Kotler, M., Weizman, A., Eliez, S., 2009. Psychiatric disorders and intellectual functioning throughout development in velocardiofacial (22q11.2 deletion) syndrome. Elsevier. J. Am. Acad. Child Adolesc. Psychiatry 48, 1060-1068.

Green, J.G., McLaughlin, K.A., Berglund, P.A., Gruber, M.J., Sampson, N.A., Zaslavsky, A.M., Kessler, R.C., 2010. Childhood adversities and adult psychiatric disorders in the national comorbidity survey replication I. American Medical Association. Arch. Gen. Psychiatry 67, 113.

Gur, R.E., Yi, J.J., McDonald-McGinn, D.M., Tang, S.X., Calkins, M.E., Whinna, D., Souders, M.C., Savitt, A., Zackai, E.H., Moberg, P.J., Emanuel, B.S., Gur, R.C., 2014. Neurocognitive development in 22q11.2 deletion syndrome: comparison with youth having developmental delay and medical comorbidities. Nature Publishing Group. Mol. Psychiatry 19, 1205-1211.

Gur, R.E., Bassett, A.S., McDonald-McGinn, D.M., Bearden, C.E., Chow, E., Emanuel, B.S., Owen, M., Swillen, A., Van den Bree, M., Vermeesch, J., Vorstman, J.A.S., Warren, S., Lehner, T., Morrow, B., 2017. A neurogenetic model for the study of schizophrenia spectrum disorders: the International 22q11.2 Deletion Syndrome Brain Behavior Consortium. Nature Publishing Group. Mol. Psychiatry 1-9.

Holtzman, C.W., Trotman, H.D., Goulding, S.M., Ryan, A.T., MacDonald, A.N., Shapiro, D.I., Brasfield, J.L., Walker, E.F., 2013. Stress and neurodevelopmental processes in the emergence of psychosis. Pergamon Neurosci. 249, 172-191.

Jacobs, N., Myin-Germeys, I., Derom, C., Delespaul, P., van Os, J., Nicolson, N.A., 2007. A momentary assessment study of the relationship between affective and adrenocortical stress responses in daily life. Biol. Psychol. 74, 60-66.

Jacobson, D., Bursch, M., Lajiness-O'Neill, R., 2016. Potential role of cortisol in social and memory impairments in individuals with 22q11.2 deletion syndrome. J. Pediatr. Genet. 05, 150-157.

Jansen, L.M.C., Gispen-de Wied, C.C., Kahn, R.S., 2000. Selective impairments in the stress response in schizophrenic patients. Springer-Verlag. Psychopharmacology 149, 319-325.

Jawahar, M.C., Murgatroyd, C., Harrison, E.L., Baune, B.T., 2015. Epigenetic alterations following early postnatal stress: a review on novel aetiological mechanisms of common psychiatric disorders. BioMed Central Clinical Epigenetics 7, 122.

Jonas, R.K., Montojo, C.a, Bearden, C.E., 2014. The 22q11.2 deletion syndrome as a window into complex neuropsychiatric disorders over the lifespan. Elsevier. Biol. Psychiatry 75, 351-360.

Kasanova, Z., Ceccarini, J., Frank, M.J., van, Amelsvoort T., Booij, J., Heinzel, A., Mottaghy, F., Myin-Germeys, I., 2017. Striatal dopaminergic modulation of reinforcement learning predicts reward-oriented behavior in daily life. Biol. Psychol. $127,1-9$.

Kendler, K.S., Karkowski, L.M., Prescott, C.A., 1999. Causal relationship between stressful life events and the onset of major depression. Psychiatry Interpersonal Biol.Process. 156, 837-841.

Kessler, R.C., McLaughlin, K.A., Green, J.G., Gruber, M.J., Sampson, N.A., Zaslavsky, A.M., Aguilar-Gaxiola, S., Alhamzawi, A.O., Alonso, J., Angermeyer, M., Benjet, C., Bromet, E., Chatterji, S., de Girolamo, G., Demyttenaere, K., Fayyad, J., Florescu, S., Gal, G., Gureje, O., Haro, J.M., Hu, C., Karam, E.G., Kawakami, N., Lee, S., Lépine, J.P., Ormel, J., Posada-Villa, J., Sagar, R., Tsang, A., Üstün, T.B., Vassilev, S., Viana, M.C., Williams, D.R., 2010. Childhood adversities and adult psychopathology in the WHO world mental health surveys. Cambridge University Press. Br. J. Psychiatry 197, 378-385.

Lovallo, W.R., Enoch, M.A., Sorocco, K.H., Vincent, A.S., Acheson, A., Cohoon, A.J., Hodgkinson, C.A., Goldman, D., 2017. Joint impact of early life adversity and COMT Val158Met (rs4680) genotypes on the adult cortisol response to psychological stress. Psychosom. Med. 79, 631-637.

Lukoff, D., Snyder, K., Ventura, J., Nuechterlein, K.H., 1984. Life events, familial stress, and coping in the developmental course of schizophrenia. Schizophr. Bull. 10, 258-292.

Ma, D., Serbin, L.A., Stack, D.M., 2018. How children's anxiety symptoms impact the functioning of the hypothalamus-pituitary-adrenal axis over time: a cross-lagged panel approach using hierarchical linear modeling. Cambridge University Press. Dev. Psychopathol. 1-15.

Mahle, W.T., Crisalli, J., Coleman, K., Campbell, R.M., Tam, V.K.H., Vincent, R.N., Kanter, K.R., 2003. Deletion of chromosome 22q11.2 and outcome in patients with pulmonary atresia and ventricular septal defect. Ann. Thorac. Surg. 76, 567-571.

Mathew, S.J., Coplan, J.D., Smith, E.L.P., Schoepp, D.D., Rosenblum, L.A., Gorman, J.M., 2001. Glutamate-Hypothalamic-Pituitary-Adrenal Axis Interactions: Implications for Mood and Anxiety Disorders, vol. 6. Cambridge University Press CNS Spectrums, pp. 555-564.

Mcdonald-Mcginn, D.M., Sullivan, K.E., Marino, B., Philip, N., Swillen, A., Vorstman,
J.A.S., Zackai, E.H., Emanuel, B.S., Vermeesch, J.R., Morrow, B.E., Scambler, P.J., Bassett, A.S., 2015. 22q11.2 deletion syndrome. Nat. Rev. Dis. Primers 1, 15071.

McDonald-McGinn, D.M., Sullivan, K.E., Marino, B., Philip, N., Swillen, A., Vorstman, J.A.S., Zackai, E.H., Emanuel, B.S., Vermeesch, J.R., Morrow, B.E., Scambler, P.J., Bassett, A.S., 2015. 22q11.2 Deletion Syndrome 1. Nature Publishing Group Nature Reviews Disease Primers, pp. 15071.

McEwen, B.S., 2004. Protection and damage from acute and chronic stress: allostasis and allostatic overload and relevance to the pathophysiology of psychiatric disorders. Ann. N. Y. Acad. Sci. 1032, 1-7.

Miller, G.E., Chen, E., Zhou, E.S., 2007. If it goes up, must it come down? Chronic stress and the hypothalamic-pituitary-adrenocortical axis in humans. Psychol. Bull. 133, $25-45$.

Moreno-Peral, P., Conejo-Cerón, S., Motrico, E., Rodríguez-Morejón, A., Fernández, A. García-Campayo, J., Roca, M., Serrano-Blanco, A., Rubio-Valera, M., Ángel Bellón, J., 2014. Risk factors for the onset of panic and generalised anxiety disorders in the general adult population: a systematic review of cohort studies. Elsevier Journal of Affective Disorders 168, 337-348.

Murphy, K.C., Jones, La, Owen, M.J., 1999. High rates of schizophrenia in adults with velo-cardio-facial syndrome. Arch. Gen. Psychiatry 56, 940-945.

Myin-Germeys, I., van Os, J., 2007. Stress-reactivity in psychosis: evidence for an affective pathway to psychosis. Pergamon Clinical Psychology Review 27, 409-424.

Myin-Germeys, I., Delespaul, P.A.E.G., deVries, M.W., 2000. Schizophrenia patients are more emotionally active than is assumed based on their behavior. Schizophr. Bull. 26, 847-854.

Myin-Germeys, I., Jim, V.O., Schwartz, J., Stone, A., Delespaul, P., 2001. Emotional reactivity to daily life stress in psychosis. Arch. Gen. Psychiatry 58, 1137-1144.

Myin-Germeys, I., Oorschot, M., Collip, D., Lataster, J., Delespaul, P., van Os, J., 2009. Experience sampling research in psychopathology: opening the black box of daily life. Psychol. Med. 39, 1533-1547.

Myin-Germeys, I., Birchwood, M., Kwapil, T., 2011. From environment to therapy in psychosis: a real-world momentary assessment approach. Oxford University Press. Schizophr. Bull. 37, 244-247.

Myin-Germeys, I., Kasanova, Z., Vaessen, T., Vachon, H., Kirtley, O., Viechtbauer, W., Reininghaus, U., 2018. Experience sampling methodology in mental health research: new insights and technical developments. Wiley-Blackwell. World Psychiatry 17, $123-132$.

Nicolson, N.A., 2008. Measurement of cortisol. Introduction to the hypothalamic-pituitary-adrenocortical axis. In: Luecken, L., Gallo, L. (Eds.), Handbook of Physiological Research Methods in Health Psychology. Sage, USA.

Oswald, L.M., McCaul, M., Choi, L., Yang, X., Wand, G.S., 2004. Catechol-O-methyltransferase polymorphism alters hypothalamic-pituitary- adrenal axis responses to naloxone: A preliminary report. Biol. Psychiatry 55, 102-105.

Overall, J.E., Gorham, D.R., 1962. The Brief Psychiatric Rating Scale 10. SAGE PublicationsSage CA, Los Angeles, CA, pp. 799-812 Psychological Reports.

Peeters, F., Nicholson, N.A., Berkhof, J., 2003. Cortisol responses to daily events in major depressive disorder. Psychosom. Med. 65, 836-841.

Phillips, L., Goodwin, J., Johnson, M.P., Campbell, L.E., 2017. Could I, should I? Parenting aspirations and personal considerations of five young women with 22q11.2 deletion syndrome. Taylor \& Francis. J. Intellect. Dev. Disabil. 42, 364-374.

Pruessner, J., Hellhammer, D., Kirschbaum, C., 1999. Burnout, perceived stress, and cortisol responses to awakening: psychosomatic medicine. Psychosom. Med. 61 197-204.

Pruessner, M., Béchard-Evans, L., Boekestyn, L., Iyer, J.C., Pruessner, A.K., 2013. Attenuated cortisol response to acute psychosocial stress in individuals at ultra [HYPHEN] high risk for psychosis. Schizophrenia research. 146 (1-3), 79-86.

Reininghaus, U., Kempton, M.J., Valmaggia, L., Craig, T.K.J., Garety, P., Onyejiaka, A., Gayer-Anderson, C., So, S.H., Hubbard, K., Beards, S., Dazzan, P., Pariante, C., Mondelli, V., Fisher, H.L., Mills, J.G., Viechtbauer, W., Mcguire, P., Van Os, J., Murray, R.M., Wykes, T., Myin-Germeys, I., Morgan, C., 2016. Stress sensitivity, aberrant salience, and threat anticipation in early psychosis: an experience sampling study. Schizophr. Bull. 42, 712-722.

Roberts, A.D.L., Wessely, S., Chalder, T., Papadopoulos, A., Cleare, A.J., 2004. Salivary cortisol response to awakening in chronic fatigue syndrome. Br. J. Psychiatry 184, 136-141.

Robins, L.N., Wing, J., Wittchen, H.U., Helzer, J.E., Babor, T.F., Burke, J., Farmer, A., Jablenski, A., Pickens, R., Regier, D.A., Sartorius, N., Towle, L.H., 1988. The composite international diagnostic interview. Am. Med. Assoc. Arch. Gen. Psychiatry 45, 1069.

Sanders, A.F.P., Hobbs, D.A., Stephenson, D.D., Laird, R.D., Beaton, E.A., 2017. Working memory impairments in chromosome 22q11.2 deletion syndrome: the roles of anxiety and stress physiology. Springer US. J. Autism Dev. Disord. 47, 992-1005.

Scandurra, V., Scordo, M.R., Canitano, R., de Bruin, E.I., 2013. 22q11 deletion syndrome and multiple complex developmental disorder: a case report. Elmer Press. J. Clin. Med. Res. 5, 135-139.

Schmand, B., Bakker, D., Saan, R., Louman, J., 1991. [The Dutch reading Test for Adults: a measure of premorbid intelligence level]. Tijdschr. Gerontol. Geriatr. 22, 15-19.

Schneider, M., Debbané, M., Bassett, A.S., Chow, E.W.C., Fung, W.L.A., Van Den Bree, M.B.M., Owen, M., Murphy, K.C., Niarchou, M., Kates, W.R., Antshel, K.M., Fremont, W., McDonald-McGinn, D.M., Gur, R.E., Zackai, E.H., Vorstman, J., Duijff, S.N., Klaassen, P.W.J., Swillen, A., Gothelf, D., Green, T., Weizman, A., Van Amelsvoort, T., Evers, L., Boot, E., Shashi, V., Hooper, S.R., Bearden, C.E., Jalbrzikowski, M., Armando, M., Vicari, S., Murphy, D.G., Ousley, O., Campbell, L.E., Simon, T.J., Eliez, S., 2014. Psychiatric disorders from childhood to adulthood in 22q11.2 deletion syndrome: results from the international consortium on brain and behavior in 22q11.2 deletion syndrome. American Psychiatric AssociationArlington. VA Am. J. Psychiatry 171, 627-639. 
Sheehan, D.V., Lecrubier, Y., Sheehan, K.H., Amorim, P., Janavs, J., Weiller, E., Hergueta, T., Baker, R., Dunbar, G.C., 1998. The Mini-International Neuropsychiatric Interview (M.I.N.I.): the development and validation of a structured diagnostic psychiatric interview for DSM-IV and ICD-10. J. Clin. Psychiatry 59 (Suppl. 20), 22-33 quiz 34-57.

Shiffman, S., Stone, A.A., Hufford, M.R., 2008. Ecological momentary assessment. Annu. Rev. Clin. Psychol. 4, 1-32.

Shprintzen, R.J., 2008. Velo-cardio-Facial syndrome: 30 years of study. Dev. Disabil. Res. Rev. 14, 3-10.

Snijders, Bosker R., 1999. Multilevel Modeling: An Introduction to Basic and Advanced Multilevel Modeling. Sage, Wiltshire, Great Britain.

Sulon, J., Demey-Ponsart, L., Beauduin, P., Sodoyez, J.C., 1978. Radioimmunoassay of corticosterone, cortisol and cortisone: their application to human cord and maternal plasma. Pergamon J. Steroid Biochem. 9, 671-676.

Swillen, A., McDonald-McGinn, D., 2015. Developmental trajectories in 22q11.2 deletion syndrome. Am. J. Med. Genet. C Semin. Med. Genet. 169, 172-181.

Swillen, A., Devriendt, K., Legius, E., Prinzie, P., Vogels, A., Ghesquiere, P., Fryns, J., 1999. The behavioural phenotype in velo-cardio-Facial syndrome (VCFS): from infancy to adolescence. Genet. Couns. 10, 79-88.

Tucker-Drob, E.M., Grotzinger, A.D., Briley, D.A., Engelhardt, L.E., Mann, F.D., Patterson, M., Kirschbaum, C., Adam, E.K., Church, J.A., Tackett, J.L., Harden, K.P., 2017. Genetic influences on hormonal markers of chronic hypothalamic-pituitary-adrenal function in human hair. Psychol. Med. 47, 1389-1401.

Vaessen, T., Kasanova, Z., Hernaus, D., Lataster, J., Collip, D., Van, Nierop M., Myingermeys, I., 2018. Psychoneuroendocrinology overall cortisol, diurnal slope, and stress reactivity in psychosis : an experience sampling approach. Elsevier. Psychoneuroendocrinology 96, 61-68.

van Duin, E.D.A., Ceccarini, J., Booij, J., Kasanova, Z., Vingerhoets, C., van Huijstee, J., Heinzel, A., Mohammadkhani-Shali, S., Winz, O., Mottaghy, F., Myin-germeys I van, A.T., 2017. Lower frontal dopamine D2/3 receptor binding in adults with 22q11.2 deletion syndrome: a $[18 \mathrm{~F}]$ fallypride positron emission tomography study. Conference Abstract 17th International ESCAP Congress 9-11 July.

Van Hoof, E., Cluydts, R., De Meirleir, K., 2003. Atypical depression as a secondary symptom in chronic fatigue syndrome. Churchill Livingstone. Med. Hypotheses 61 $52-55$.

van Venrooij, J.A.E.M., SBAHA, Fluitman, Lijmer, J.G., Kavelaars, A., Heijnen, C.J.,
Westenberg, H.G.M., Kahn, R.S., Gispen-de Wied, C.C., 2012. Impaired neuroendocrine and immune response to acute stress in medication-naive patients with a first episode of psychosis. Oxford University Press. Schizophr. Bull. 38, 272-279.

Van Winkel, R., Henquet, C., Rosa, A., Papiol, S., Faňanás, L., De Hert, M., Peuskens, J., Van Os, J., Myin-Germeys, I., 2008. Evidence that the COMTVal158Met polymorphism moderates sensitivity to stress in psychosis: an experience-sampling study. Am. J. Med. Genet. Part B Neuropsychiatr. Genet. 147, 10-17.

Varese, F., Smeets, F., Drukker, M., Lieverse, R., Lataster, T., Viechtbauer, W., Read, J., van Os, J., Bentall, R.P., 2012. Childhood adversities increase the risk of psychosis: a meta-analysis of patient-control, prospective- and cross-sectional cohort studies. Oxford University Press. Schizophr. Bull. 38, 661-671.

Vergaelen, E., Claes, S., Kempke, S., Swillen, A., 2017. High Prevalence of Fatigue in Adults With a 22q11.2 Deletion Syndrome. Wiley-Blackwell. Am. J. Med. Genet. A $173,858-867$

Vo, O.K., McNeill, A., Vogt, K.S., 2018. The psychosocial impact of 22q11 deletion syndrome on patients and families: a systematic review. Am. J. Med. Genet. A.

Vorstman, J.A., Morcus, M.E., Duijff, S.N., Klaassen, P.W., HEINEMAN-de Boer, J.A., BEEMER, F.A., SWAAB, H., KAHN, R.S., van ENGELAND, H., 2006. The 22q11.2 deletion in children. J. Am. Acad. Child Adolesc. Psychiatry 45 (9), 1104-1113. https://doi.org/10.1097/01.chi.0000228131.56956.c1.

Wechsler, D., 1997. WAIS-III Administration and Scoring Manual. The Psychological Corporation. The Psychological Corporation, San Antonio, Texas.

World Medical Association, 2001. WMA Declaration of Helsinki-ethical principles for medical research involving human subjects. Bull. World Health Organ. 79, 373.

Yehuda, R., 2002. Post-traumatic stress disorder. N. Engl. J. Med. 346, 108-114.

Yehuda, R., Teicher, M.H., Trestman, R.L., Levengood, R.A., Siever, L.J., 1996. Cortisol regulation in posttraumatic stress disorder and major depression: a chronobiological analysis. Biol. Psychiatry 40, 79-88.

Yi, J.J., Weinberger, R., Moore, T.M., Calkins, M.E., Guri, Y., McDonald-McGinn, D.M., Zackai, E.H., Emanuel, B.S., Gur, R.E., Gothelf, D., Gur, R.C., 2016. Performance on a computerized neurocognitive battery in 22q11.2 deletion syndrome: a comparison between US and Israeli cohorts. Brain Cogn. 106, 33-41.

Zorn, J.V., Schür, R.R., Boks, M.P., Kahn, R.S., Joëls, M., Vinkers, C.H., 2017. Cortisol stress reactivity across psychiatric disorders: a systematic review and meta-analysis. Elsevier Ltd. Psychoneuroendocrinology 77, 25-36. 